The International Journal of Indian Psychology

ISSN 2348-5396 (e) | ISSN: 2349-3429 (p)

Volume 3, Issue 4, No. 59, DIP: 18.01.064/20160304

ISBN: 978-1-365-26307-1

http://www.ijip.in | July-September, 2016

\title{
Attitude of Secondary School Teachers towards Cultural Activities
}

\author{
Ms. Manisha ${ }^{1 *}$
}

\section{ABSTRACT}

The present investigation was to find the attitude of secondary school teachers towards cultural activities. Survey method of investigation was employed. The findings of the study showed that there is no significant difference between male and female secondary school teachers in relation to their attitude towards cultural activities. Significant difference was obtained between rural and urban secondary school teachers in relation to their attitude towards cultural activities. Significant difference was also found between govt. and non-govt. secondary school teachers in relation to their attitude towards cultural activities.

Keywords: Attitude, Secondary School teachers and Cultural Activities.

The first school of a child is his family and society. Every society has its certain norms, traditions, customs, rearing practices and social environment. These customs and traditions are acquired from their previous generations and so on. These customs and traditions form the culture of a society. The learning of these cultural activities influence the life of a child to a great extend along with the other kinds of learning. Thus to have a look inside the learning of the child, it becomes important to understand the culture in which the child is being reared. To enhance the culture of a society, there arises a need to inculcate the cultural trends in the child as an additional responsibility of the teachers in the schools. These responsibilities come under the term cultural activities. Cultural activities are those educational activities which are generally pursued outside the classroom but are considered to be an inseparable, essential and integral part of the school curriculum.

\section{METHODOLOGY}

The present study is a survey type in nature. Here the data has been collected personally from the teachers. The method applied is of descriptive type. Purposive sampling method was used to select the schools.

\footnotetext{
${ }^{1}$ Assist. Prof. S.S.G.D.C.O.E, Panchkula Haryana, India *Responding Author

(C) 2016 I Manisha; licensee IJIP. This is an Open Access Research distributed under the terms of the Creative Commons Attribution License (http://creativecommons.org/licenses/by/2.0), which permits unrestricted use, distribution, and reproduction in any Medium, provided the original work is properly cited.
} 


\section{Attitude of Secondary School Teachers towards Cultural Activities}

\section{Sample}

A sample of 200 secondary school teachers was selected from 10 government and nongovernment schools of Panchkula district of Haryana state.

\section{Objectives}

1. To study the attitude towards cultural activities of male and female secondary school teachers.

2. To study the attitude towards cultural activities of govt. and non- govt. secondary school teachers.

3. To study the attitude towards cultural activities of rural and urban secondary school teachers.

\section{Hypotheses}

1. There exists a significant difference between male and female secondary school teachers in relation to their attitude towards cultural activities.

2. There exists a significant difference between govt. and non-govt. secondary school teachers in relation to their attitude towards cultural activities.

3. There exists a significant difference between rural and urban secondary school teachers in relation to their attitude towards cultural activities.

\section{Tool Used}

Attitude scale developed by the investigator was used for the collection of the data. The scale consisted of 30 statements, which were selected from relevant literature and consultation of experts.

\section{RESULTS AND DISCUSSIONS}

Table 1: showing difference between male and female secondary school teachers in relation to their attitude towards cultural activities

\begin{tabular}{|l|l|l|l|l|l|}
\hline Sr. No. & N & Mean & S.D. & SEM & t- value \\
\cline { 1 - 4 } & 100 (males) & 60.48 & 18.23 & 1.823 & 1.0333 \\
\hline 2 & 100 (females) & 57.99 & 15.76 & 1.576 & \\
\hline
\end{tabular}

It is observed from the table that the t- value is 1.0333 which is not significant. Thus it shows that males and females do not show significant difference in relation to their attitude towards cultural activities. Therefore, hypothesis no. 1 i.e. There exists a significant difference between male and female secondary school teachers in relation to their attitude towards cultural activities, is rejected. 
Table 2: showing difference between govt. and non-govt. secondary school teachers in relation to their attitude towards cultural activities.

\begin{tabular}{|l|l|l|l|l|l|}
\hline Sr. No. & N & Mean & S.D. & SEM & t- value \\
\cline { 1 - 5 } & 100 (govt.) & 62.07 & 16.46 & 1.646 & 2.807 \\
\cline { 1 - 4 } & 100 (non-govt.) & 55.99 & 14.08 & 1.408 & \\
\hline
\end{tabular}

It is observed from the table that the t- value is 2.807 which is significant. Thus it shows that govt. and non- govt. secondary school teacher show significant difference in relation to their attitude towards cultural activities. Therefore, hypothesis no. 2 i.e. There exists a significant difference between govt. and non-govt. secondary school teachers in relation to their attitude towards cultural activities is accepted.

Table 3: showing difference between rural and urban secondary school teachers in relation to their attitude towards cultural activities

\begin{tabular}{|l|l|l|l|l|l|}
\hline Sr. No. & N & Mean & S.D. & SEM & t- value \\
\hline 1 & 100 (rural & 64.82 & 19.67 & 1.967 & 4.153 \\
\cline { 1 - 4 } 2 & 100 (urban) & 53.93 & 17.34 & 1.734 & \\
\hline
\end{tabular}

It is observed from the table that the t- value is 4.153 which is significant. Thus it shows that rural and urban teachers show significant difference in relation to their attitude towards cultural activities. Therefore, hypothesis no. 3 i.e There exists a significant difference between rural and urban secondary school teachers in relation to their attitude towards cultural activities is accepted.

\section{CONCLUSIONS}

On the basis of the present study the following conclusions have been drawn:

1. There exists a no significant difference between male and female secondary school teachers in relation to their attitude towards cultural activities.

2. There exists a significant difference between govt. and non-govt. secondary school teachers in relation to their attitude towards cultural activities.

3. There exists a significant difference between rural and urban secondary school teachers in relation to their attitude towards cultural activities.

\section{SUGGESTIONS}

- $\quad$ Cultural activities should be made an integral part of school curriculum.

- $\quad$ Teachers should be trained in organizing cultural activities during their pre service and in service trainings.

- $\quad$ Interest should be inculcated in the minds of the students to serve their nation.

- Schools administrators and organizers should encourage the students to participate in cultural activities and should provide sufficient materials in schools for different types of cultural activities.

- $\quad$ The responsibility of planning and organizing the cultural activities should be assigned to those teachers who have taste in the same.

(C) The International Journal of Indian Psychology, ISSN 2348-5396 (e)| ISSN: 2349-3429 (p) | 73 


\section{Attitude of Secondary School Teachers towards Cultural Activities}

- There should be provision for cultural activities at primary school level so that the students may develop interest in cultural activities from very beginning.

\section{Acknowledgments}

The author appreciates all those who participated in the study and helped to facilitate the research process.

\section{Conflict of Interests}

The author declared no conflict of interests.

\section{REFERENCES}

Austin, G. G. (1979). The effects of Student Teaching and Pre Teaching on Student Teacher's Attitude towards Cultural Activities. The Journal of experimental education, vol. 48, 36-38.

Beena, S. (1995). Determinants of Teaching Effectiveness, The Indian Publications, Ambala Cantt., Haryana, India.

Benjamin,L.T.; Hopkins, N. \& Jack, R. (1990). Book on Psychology, Macmillan Publication co., 866 Third Avenue, new York, p495.

Bexter, A. G. (1993). Improving Teaching Candidates' Attitude towards culture. Teacher Education and Practice, Vol. 8 (2), 15-25.

Coleman, A. M. (2001). Dictionary of Psychology. Oxford University Press, New Delhi.

Coleman, J.C. (1973). Psychology and Effective Behaviour. D.B. Taraporevala Sons and Co. Pvt. Ltd, New Delhi.

Dinkmeyer, D.C. (1967). Child Development. Prentice Hall of India Pvt. Ltd., New Delhi.

Goyal, J. C. (1980). A study of the relationship among Attitude, Job Satisfaction, Adjustment and Professional Interest of teacher Educators in India. Butch Third Survey of research in Eduation, NCERT, New Delhi.

Jerslid, A.t. (1968). Educational Psychology, Prentice Hall of India Pvt. Ltd., New Delhi.

Pederson, J. E. \& McCurdy, D. W. (1992). The Effects of hands on mind on teaching experience on attitudes of pre-service elementary teachers to cultural activities. Science Education, vol. 76 (2), 141-146.

Ranganathan, V. (2008). Interest in cultural activities and teacher Aptitude of D.T.Ed. Students, journal of Psychological Researches, Vol.52 (1), 47-49.

Rodger, S. (2007). Effects of Teacher Clarity and Student interest in cultural activities. Doctoral Thesis, Teaching Training Institute, Andhra Pradesh.

Sajan, K. S. (1999). A Study of Teaching Aptitude of Student Teachers, Doctoral Dissertation, University of Calicut.

Taiwo, D. (1980). The Influence of previous Exposure to cultural activities on Attitude of Preservice Science Teachers towards Science Teaching, Vol. 17, 84-89.

Yeh, Y. (2007). Aptitude treatment Instructions in Pre-service teachers' Behaviour Change during culture related Teaching. Doctoral thesis, Nagaland University.

How to cite this article: Manisha (2016), Attitude of Secondary School Teachers towards Cultural Activities, International Journal of Indian Psychology, Volume 3, Issue 4, No. 59, ISSN 2348-5396 (e), ISSN: 2349-3429 (p), DIP: 18.01.064/20160304, ISBN: 978-1-365-26307-1 